\title{
FGF13 wt Allele
}

National Cancer Institute

\section{Source}

National Cancer Institute. FGF13 wt Allele. NCI Thesaurus. Code C118514.

Human FGF13 wild-type allele is located in the vicinity of Xq26.3 and is approximately 591 $\mathrm{kb}$ in length. This allele, which encodes fibroblast growth factor 13 protein, is involved in microtubule polymerization, neural development and neuronal migration. Deletion of the region of the X chromosome where the gene is located is associated with BorjesonForssman-Lehmann syndrome. 